\title{
Engaging With Gifted Education's Past to Inform the Present and the Future
}

\author{
Jennifer L. Jolly ${ }^{1}$ and Russell T. Warne ${ }^{2}$ \\ ${ }^{1}$ Department of Special Education and Multiple Abilities, University of Alabama \\ ${ }^{2}$ Department of Behavioral Science, Utah Valley University
}

\begin{abstract}
Author Note
Jennifer L. Jolly (D) https://orcid.org/0000-0002-3848-3701

Russell T. Warne (D) https://orcid.org/0000-0003-4763-3625

We have no conflicts of interest to disclose.

Correspondence concerning this article should be addressed to Jennifer L. Jolly, Graves
\end{abstract} Hall Box 87032, Tuscaloosa, AL 35404. Email: jljolly1@ua.edu 
This manuscript was originally intended to be the introduction of the January 2021 special issue of Gifted Child Quarterly, exploring the influence of Lewis Terman's landmark longitudinal of 1,528 gifted children, which was begun in 1921. On July 22, 2020, the NAGC Board of Directors voted to not publish the special issue, which had been in progress for nearly two years. As all of the articles for the special issue had already been accepted, they have been released on GCQ's website as online first articles and will subsequently be released in print over three issues in October 2020, January 2021, and April 2021. However, the articles lack the background and context that a special issue would provide. Therefore, we are making some of this context available by posting online this document, which was to serve as the introduction to the special issue. Providing this introduction with links (found in the reference list) to the published articles is our effort to preserve the original intent of the special issue and provide a scholarly view of Terman's longitudinal study and his larger body of work.

Guest Editors

Jennifer L. Jolly, University of Alabama

Russell T. Warne, Utah Valley University 


\section{Engaging With Gifted Education's Past to Inform the Present and the Future}

Why does a study conducted 100 years ago warrant attention in the field of gifted education today, two decades into the 21 st century? Terman's longitudinal study, along with Leta Hollingworth's work and the pioneering efforts of several other scientists (e.g., Guy Whipple, Lulu Stedman, J. Paul Witty, and Martin Jenkins) during the early decades of the 20th century, laid the foundations for the field and for the scholarly study of gifted education. Despite the importance of these individuals' contributions, Terman's Genetic Studies of Genius (GSG) exerts a disproportionate influence on the field. This study shaped and formed the field, leaving an indelible imprint — for better and for worse - that remains today. It is impossible to divorce Terman's work, including the GSG, from the field of gifted education.

Aside from the impact of the study, it is valuable that scholars and practitioners in gifted education understand their discipline's history. NAGC's 2019 Pre-K-12 Gifted Programming Standards acknowledges that in professional learning "educators understand how knowledge, perspectives, and historical and current issues influence professional practice and the education and treatment of individuals with gifts and talents both in school and society" (Standard 6.3.3, p. 17). The 2013 NAGC-CEC Teacher Preparation Standards in Gifted and Talented Education reiterates this same set of knowledge and skills in Standard 6.2.

Scholarly endeavors like this special issue can aid in furthering the field's understanding of its earliest scholars and their findings. Based on our previous historical research (Jolly, 2018; Warne, 2019), we understand how Terman's longitudinal study and his entire body of work have left a fraught and complex legacy that has yet to be reconciled with the ethical understandings of the 21 st century and modern conceptions of giftedness. The influence of and contributions arising from this study are not limited to gifted education; other fields, including psychology, 
educational psychology, and educational measurement, also reference this work (see Hodges et al., 2020). These fields also must come to their own understandings regarding Terman's work in relation to their current theories and research questions.

This special issue explores the influence of the GSG and offers a reassessment of this historic research, much like the 1990 Roeper Review special issue on Leta Hollingworth that initiated a greater understanding of her contributions to gifted education. The present issue includes a bibliometric analysis of the influence of the GSG (Hodges et al., 2020), the first quantitative analysis of the breadth and depth of the GSC's influence. Two of the articles report replications of selected findings from Terman's longitudinal study (Bergold et al., 2020; Lubinski \& Benbow, 2020). The Lubinski and Benow article includes a summary of research from the Study of Mathematically Precocious Youth (SMPY). The GSG informed Julian Stanley as he developed and planned SMPY, and the research of Stanley and his successors has replicated, extended, and updated the findings from Terman's longitudinal research. There is also an in-depth discussion of Catherine Cox's contribution to the Genetic Studies of Genius series (Simonton, 2020). Finally, Carole K. Holahan, the only remaining author of an official volume from the GSG (Holahan \& Sears, 1995), reports about the longitudinal study’s members' aging process (Holahan, 2020).

These contributions to the research literature are not sufficient to discuss the totality of the GSG or of Terman's work. It is important to recognize what is missing from these analyses of the GSG in the context of the 21 st century. For example, a discussion of Terman's beliefs about women and sex differences is a fertile area for future inquiry. Leadership as a domain of giftedness is underexplored, and Terman's ideas about eminence, leadership, and "genius" could 
be relevant to modern theorists and practitioners, given the importance of leadership in the Marland Report and in many state definitions of giftedness (NAGC, forthcoming).

Most controversial, though, are Terman's attitudes towards race. Neither of us has ever minimized or excused the derogatory and racist ideas that Terman published when discussing children from non-White demographic groups (e.g., Jolly, 2008a, 2008b; Jolly, 2018; Warne, 2019, 2020; Winkler \& Jolly, 2014). We also find his advocacy for eugenics (a position Terman later distanced himself from) to be inexcusable, and his participation in a social movement that robbed people — who disproportionately belonged to low-income and marginalized groups—of their dignity, freedom, and human rights will forever be a stain upon his name. Historical facts are often complex. The sobering histories offered by scholarly sources on the early 20th-century eugenics movement (e.g., Amy \& Rowlands, 2018a, 2018b; Grodin et al., 2018; Kevles, 1995; Stern, 2005) and of Terman's writings and actions within it (e.g., Beauvais, 2016; Minton, 1988; Warne, 2019) should inform these complex understandings.

Although the early 20th-century eugenicists' influence has nearly fully waned, the realities of a racially unequal society stubbornly persist. It is impossible to ignore the range of ways that there are unequal outcomes among racial groups in the United States. Important average differences across racial groups persist in home ownership rates, achievement gaps, college completion rates, income, incarceration rates, and many more areas. The tragic deaths of George Floyd and the other African Americans who have been killed in police custody are categorical examples of the persistent systemic racial inequalities that are so evident in American society.

For gifted education, one way these inequities manifest themselves is disproportionate representation in gifted programs, with most students of Asian American and White backgrounds 
being identified at higher rates than Hispanic and African American students. The causes of racial inequality in gifted education are hotly contested, but this pattern of disproportionate participation dates back to Terman's era and was manifested in the 95-99\% White sample that participated in the GSG. Gifted education currently has a community of scholars who have turned their attention toward remedying this disproportionality (e.g., McBee, 2010; Moore et al., 2005; Olszewski-Kubilius et al., 2017; Peters et al., 2019; Ricciardi et al., 2020; Worrell \& Dixson, 2018), but fully satisfactory solutions remain elusive. Still, diverse students have never had more advocates in gifted education than they do now, and we support continued efforts to remedy this inequality - and others - experienced by African American, Hispanic, low-income, and other historically marginalized gifted children.

Bad actors abound throughout history, including in the field of gifted education. The test for members of contemporary society is in how they use the knowledge of the past. History can be used as a tool to help influence the present and guide the future, but this requires accurate knowledge and critical reflection about historical facts. This type of reflection also provides a maturing field the opportunity to consider changes over time, specific individuals' contributions and actions, or a specific event from a modern perspective as well as within the historical context. Historical deliberation is important because "if we refuse to listen to history, we will find ourselves fabricating a past that reinforces our understanding of current problems" (Crabtree, 1993, para. 57). The past and the present converge in this special issue. Ignoring, dismissing, or erasing Terman's work-or the contributions of any other pioneers in gifted education - prevents contemporary scholars from using information from the past to shape a better future for the field. A choice to not discuss history allows the past to wield its influence in 
a covert manner, which inhibits thoughtful change and distorts a community's understanding of the present.

All scholars would agree that the GSG is an incomplete piece of research and reflective of the belief systems held by many influential scholars during the early 20 th century. The articles presented in this special issue engage with the GSG using a variety of methodologies, viewpoints, and stages of the study. The authors whose work is published in this issue have the benefit of a century of accumulated wisdom and a broader ethical framework than gifted education had 100 years ago. We appreciate their contributions to the scholarly literature and hope that this issue is a catalyst for a new body of research that critically interrogates and analyzes gifted education's past.

We would like to express our gratitude to the Gifted Child Quarterly editors, Jill Adelson and Michael S. Matthews, for their support of the special issue and the guidance provided to us. Finally, our appreciation extends to the diverse group of peer reviewers for this issue, as reviewers are the cornerstone of the publication process. When this issue was conceived, we could not have anticipated the recent transformation of American society, including the COVID19 pandemic and the resurgence of the Black Lives Matter movement on a momentous and impactful scale. These events provide an additional lens through which to understand gifted education's past, present, and future. 


\section{References}

*Denotes article originally accepted to be part of the special issue.

Amy, J.-J., \& Rowlands, S. (2018a). Legalised non-consensual sterilisation - eugenics put into practice before 1945, and the aftermath. Part 1: USA, Japan, Canada and Mexico. The European Journal of Contraception \& Reproductive Health Care, 23(2), 121-129. https://doi.org/10.1080/13625187.2018.1450973

Amy, J.-J., \& Rowlands, S. (2018b). Legalised non-consensual sterilisation - eugenics put into practice before 1945, and the aftermath. Part 2: Europe. The European Journal of Contraception \& Reproductive Health Care, 23(3), 194-200. https://doi.org/10.1080/13625187.2018.1458227

Beavais, C. (2016). California genius: Lewis Terman's gifted chid in regional perspective. Paedagogica Historica, 52, 748-765. https://doi.org/10.1080/00309230.2016.1243138

*Bergold, S., Wirthwein, L., \& Steinmayr, R. (2020). Similarities and differences between intellectually gifted and average-ability students in school performance, motivation, and subjective well-being. Gifted Child Quarterly, 65(1). https://doi.org/10.1177/0016986220932533

Crabtree, D. (1993). The importance of history. https://gutenberg.edu/2001/02/the-importanceof-history/

Grodin, M. A., Miller, E. L., \& Kelly, J. I. (2018). The Nazi physicians as leaders in eugenics and "euthanasia": Lessons for today. American Journal of Public Health, 108, 53-57. https://doi.org/10.2105/ajph.2017.304120 
*Hodges, J., Munn, R., Overross, M., \& Ottwein, J. (2020). Assessing the scholarly reach of Terman's work. Gifted Child Quarterly, 65(1). https://doi.org/10.1177/0016986220928322

*Holahan, C. K. (2020). Achievement across the life span: Perspectives from the Terman study of the gifted. Gifted Child Quarterly, 65(1). https://doi.org/10.1177/0016986220934401

Holahan, C. K., \& Sears, R. R. (1995). The gifted group in later maturity. University of Stanford Press.

Jolly, J. L. (2008a). Genetic Study of Genius--elementary school students. Gifted Child Today, 31(1), 27-33. https://doi.org/10.4219/gct-2008-689

Jolly, J. L. (2008b). A paradoxical point of view: Lewis M. Terman. Gifted Child Today, 31(2), 36-37. https://doi.org/10.4219/gct-2008-757

Jolly, J. L. (2018). A history of American gifted education. Routledge.

Kevles, D. J. (1995). In the name of eugenics: Genetics and the uses of human heredity. Harvard University Press.

*Lubinksi, D., \& Benbow, C. (2020). Intellectual precocity: What have we learned since Terman? Gifted Child Quarterly, 65(1). https://doi.org/10.1177/0016986220925447

McBee, M. (2010). Examining the probability of identification for gifted programs for students in Georgia elementary schools: A multilevel path analysis study. Gifted Child Quarterly, 54(4), 283-297. https://doi.org/10.1177/0016986210377927

Minton, H. L. (1988). Lewis M. Terman: Pioneer in psychological testing. New York University Press. 
Moore, J. L., III, Ford, D. Y., \& Milner, H. R. (2005). Recruitment is not enough: Retaining African American students in gifted education. Gifted Child Quarterly, 49(1), 51-67. https://doi.org/10.1177/001698620504900106

NAGC. (forthcoming). 2018-2019 State of the states in gifted education. Author.

NAGC. (2019). Pre-K-12 Gifted Programming Standards. Author.

NAGC. (2013). NAGC-CEC teacher preparation standards in gifted education. Author.

Olszewski-Kubilius, P., Steenbergen-Hu, S., Thomson, D., \& Rosen, R. (2017). Minority achievement gaps in STEM: Findings of a longitudinal study of Project Excite. Gifted Child Quarterly, 61(1), 20-39. https://doi.org/10.1177/0016986216673449

Peters, S. J., Rambo-Hernandez, K., Makel, M. C., Matthews, M. S., \& Plucker, J. A. (2019). Effect of local norms on racial and ethnic representation in gifted education. AERA Open, 5(2), 2332858419848446. https://doi.org/10.1177/2332858419848446

Ricciardi, C., Haag-Wolf, A., \& Winsler, A. (2020). Factors associated with gifted identification for ethnically diverse children in poverty. Gifted Child Quarterly. https://doi.org/10.1177/0016986220937685

*Simonton, D. K. (2020). Galton, Terman, \& Cox: The distinctive Volume II in Genetic Studies of Genius. Gifted Child Quarterly, 65(1). https://doi.org/10.1177/0016986220921360

Stern, A. M. (2005). Sterilized in the name of public health. American Journal of Public Health, 95, 1128-1138. https://doi.org/10 2105/ajph.2004.041608

Warne, R. T. (2019). An evaluation (and vindication?) of Lewis Terman: What the father of gifted education can teach the 21st century. Gifted Child Quarterly, 63(1), 3-21. https://doi.org/10.1177/0016986218799433 
Warne, R. T. (2020). In the know: Debunking 35 myths about human intelligence. Cambridge University Press.

Winkler, D. L., \& Jolly, J. L. (2014). Lewis M. Terman: A misunderstood legacy (1877-1956). In A. Robinson \& J. L. Jolly (Eds.), A century of contributions to gifted education: Illuminating lives (pp. 64-78). Routledge.

Worrell, F. C., \& Dixson, D. D. (2018). Recruiting and retaining underrepresented gifted students. In S. I. Pfeiffer (Ed.), Handbook of giftedness in children: Psychoeducational theory, research, and best practices (pp. 209-226). Springer International Publishing. https://doi.org/10.1007/978-3-319-77004-8_13 